\title{
Alcohol use, abuse and dependence among elderly in outpatient treatment through the application of AUDIT
}

\author{
Patrícia Cristina De Oliveira Garcia' \\ (iD) Débora Pastore Bassitt ${ }^{2}$ \\ Fernando Campos Gomes Pinto ${ }^{3}$
}

\begin{abstract}
1. Mestranda em Ciências da Saúde pelo lamspe; especialista em Saúde Mental e Psiquiatria pela Unifesp e docente do curso de Enfermagem da Universidade Nove de Julho, São Paulo, SP, Brasil. 2. Doutora em Ciências da Saúde pela FMUSP, professora de pós-graduação do lamspe, médica psiquiatra do Ipq-HCFMUSP, São Paulo, SP, Brasil. 3. Doutor em Ciências (Fisiopatologia Experimental) pela Universidade de São Paulo - Brasil, médico neurocirurgião do Hospital das Clínicas da Faculdade de Medicina da USP, São Paulo, SP, Brasil.
\end{abstract}

http://dx.doi.org/10.1590/1806-9282.66.3.307

\section{SUMMARY}

OBJECTIVE: To identify or use alcohol abuse and abuse in the IAMSPE elderly, through the application of AUDIT, socioeconomic characterization of the elderly, and problems associated with drinking and weight, if there is a relationship between depression and alcohol abuse.

METHODS: This is a cross-sectional, exploratory, and descriptive study with a quantitative approach. One hundred elderly patients were interviewed to apply a socioeconomic form and to assess alcohol consumption from AUDIT.

RESULTS: correlation between alcohol consumption and female gender ( $p=0.021$. Most of the participants were between 60 and 79 years old, were female, had a partner, had completed elementary school, had income and selected house, were retired and unemployed.

CONCLUSION: In the present study, we found no correlation between alcohol abuse and depression; Only one correlation was found between male gender and higher alcohol abuse. However, a significant prevalence of moderate use of high alcohol was found (3.9\% in women and $21.7 \%$ in men), i.e., it poses a risk to the health of the elderly.

KEYWORDS: Health of the elderly. Alcoholism. Alcohol-related disorders.

\section{INTRODUCTION}

According to the World Health Organization (WHO), all individuals aged 60 years or more are considered elderly. However, for public policymaking, there may be variations in the limit proposed by the WHO according to the characteristics and conditions of each country. It is worth noting that the minimum age adopted does not serve exclusively as a marker for the changes that accompany aging; there can be large variations in the level of participation in society, health, and independence among the elderly in different scenarios'.

Aging is a natural physiological process that starts at birth and culminates with death. Regarding its physiological aspect, the elderly have reduced the capacity of homeostatic adaptation according to situations in which the body feels a functional overload. In addition, 
it includes changes in professional and social roles, as well as losses of psychological, emotional, and motor nature ${ }^{2}$.

The Brazilian Institute of Geography and Statistics (IBGE) 3 highlights that the Brazilian population will continue to grow until 2042, reaching 228.4 million people, and, from the following year, will decrease gradually, reaching around 218.2 million in 2060. Life expectancy at birth should reach 80 years in 2041, reaching 81.2 years in 2060. Regarding gender, life expectancy at birth in 2013 reached 71.3 years for males and 78.5 years for females, and, for 2060, the projection indicates 78.0 and 84.4 years, respectively ${ }^{3}$.

However, individual variables, such as lifestyle, socioeconomic conditions, chronic diseases, smoking, alcoholism, family and social role, and presence of support by family members and friends, among others related to the aging process, contribute to healthy aging or with the emergence of chronic-degenerative diseases ${ }^{4}$.

Functional independence and autonomy are currently considered as the real indicators of the health conditions of the elderly, which may or may not present aggravating factors. Postural instability is one example because, in addition to causing a risk of falls, it can also cause emotional damage, such as depression ${ }^{5}$.

Discussions on the consumption of alcohol usually refer to young people due to the damage caused to this group, such as violent deaths and accidents. However, the elderly have resorted to the use of this substance as a "escape valve" to face the changes during aging. The loss of loved ones, absence of an important role in society and within the family, a dependency of others to perform activities of daily living (ADLs), or even the financial dependence for food and shelter can generate frustrations, resulting in stimuli for dependency ${ }^{6.7}$.

Regarding the effects and consequences of alcohol, there are no clear boundaries between use, abuse, and dependence. However, use is defined as the consumption of any substance sporadically; abuse is when, as a result of consumption, there is some kind of injury (biological, psychological, or social); and dependence is when there is a loss of control, usually associated with serious problems for the user ${ }^{8}$.

The levels and patterns of alcohol consumption, as well as the magnitude of the problems related to its use by various populations, are influenced by both individual factors (age, sex, health condition, among others) and social (economic development, culture, availability of alcohol, among others), associated with the quality of the product, context, and the motivations for consumption, besides the individuals personal vulnerability, indicating a multi-factor interaction ${ }^{9}$.

Several countries have adopted, due to the harmful effects of alcohol, clear definitions of low-risk consumption, and the standard dose of alcohol. The "standard dose" refers to the measurement of the amount of pure ethanol contained in alcoholic beverages. For the WHO, this dose is approximately 10-12 grams of ethanol (corresponding to a $330 \mathrm{ml}$ beer can, or a 100 $\mathrm{ml}$ glass of wine, or $30 \mathrm{ml}$ of a distilled drink). As for "low risk", it is considered when two doses are not consumed per day, and the individual spends at least two days without drinking. This recommendation is for both sexes ${ }^{10}$.

Considering the above about the aging process, vulnerabilities and the use of alcohol by the elderly, specifically, is described as a complex, multifactorial, and misunderstood problem, like an invisible epidemic since it is underestimated and poorly identified, either for reasons arising from the elderly themselves, such as guilt and fear, by a stereotypical perspective of health professionals or even due to the lack of technical skills ${ }^{11-13}$.

Nevertheless, the management of care for the elderly must comprise all spheres of life because when individuals live in social isolation or even alone, with losses in social, occupational, or leisure activities due to the use of alcohol, their existence and habits go unnoticed, and, sometimes, the person is ignored or neglected ${ }^{14}$.

It is worth mentioning that biological and physiological changes related to aging affect the absorption, metabolism, and elimination of alcohol, causing a decline in the liver and renal functions, and even in drug interactions, causing various problems ${ }^{15}$.

It is important to emphasize that the presence of depression is also considered a strong risk factor for other health problems, such as the use/abuse of alcohol and other drugs. This psychopathology is characterized by negative symptoms, such as mood predominantly depressed and/or irritable, anhedonia, tiredness, fatigue, disinterest, slowing, pessimistic thoughts and ideas of ruin, in addition to poor sleep quality, changes in appetite, among others, which predispose depressed patients to make use of alcohol to reduce the discomfort of symptoms ${ }^{16.17}$. 
Still, sometimes depression is underdiagnosed and undertreated, possibly due to the criteria used by the professional or due to the professional's difficulty in recognizing depressive symptoms in relation to the aging process, or even due to the lack of management during anamnesis ${ }^{18}$.

As in any pathology, early diagnosis is essential for its prognosis. In the case of alcoholism, the instrument Alcohol Use Disorders Identification Test (AUDIT), developed by WHO and already validated for the Brazilian population, is used for the assessment with the purpose of identifying drinkers at risk; measure consumption, symptoms, and the personal and social consequences of drinking; identify the alcohol experience both in the previous year as over the course of life, applicable in various scenarios, as well as to identify risk levels, suggesting their respective interventions ${ }^{19}$.

The AUDIT instrument is a questionnaire consisting of 10 questions that evaluate the behavior of the individual in relation to alcohol consumption. Three of the questions assess the amount and frequency of use, three investigate the symptoms related to dependence, and four refer to problems resulting from alcohol consumption that occurred in the previous year. Therefore, four different patterns of consumption can be identified: low-risk use (which probably does not lead to problems), risk use (which may lead to problems), harmful use (consumption that probably already has led to problems), and probable dependency ${ }^{9.19}$.

Thus, the aim of this study was to identify the use, abuse, and dependence of alcohol in elderly patients from an outpatient clinic - Iamspe - through AUDIT, considering the socioeconomic characterization of the elderly population and the problems associated with consumption and whether there is a relationship between depression and abusive use or alcohol dependence.

\section{METHODS}

It is a cross-sectional, exploratory, and descriptive field study with a quantitative approach ${ }^{20}$.

The research was carried out in outpatient clinics of Geriatrics and Psychiatry of the Institute of Medical Assistance to the Public Servants of the State of São Paulo (- Iamspe), located in São Paulo/SP. The data collection took place between June and August of 2015.

The study population consisted of patients treated in those outpatient clinics. We included patients of both sexes, treated in outpatient clinics of Geriatrics (without a diagnosis of depression) and Psychiatry (with a diagnosis of depression), with age greater than or equal to 60 years, presenting good cognitive level, i.e., with the ability to understand and respond the form and the questionnaire clearly, and to agree and sign the Informed Consent Form (ICF). We excluded patients who did not meet the above criteria established by the groups, or who did not have a minimum cognitive capacity.

The data collection occurred randomly, once or twice a week, during the morning and before the individual's medical appointment. Since this was in an outpatient clinic, patients, in their majority, arrived before the time scheduled, and their records were already separated by the collaborators of the sector. Once the records were available, the diagnosis was read and identified. The patients at the Geriatrics outpatient clinic were selected based on the inclusion criteria and without a diagnosis of depression; this same selection dynamic was used in the Psychiatry outpatient clinic, but patients needed to have a diagnosis of depression. At this stage, the goal was only to separate and select records. Individually, we invited the subjects to participate in the research, explaining its objectives and the subsequent stages. After they agreed to participate, they were asked to sign the informed consent form. After collection, the data were tabulated using Statistical Package for the Social Sciences (SPSS), version 17.0, and analyzed later. We observed the need for increasing our sample, initially of 60 patients, so it was increased to 100 . Of these, 50 patients were from the Geriatrics outpatient clinic without a diagnosis of depression, and the other 50 from the Psychiatric outpatient clinic with a diagnosis of depression. The new data collection took place in the same outpatient clinics from October to December 2015.

The first step after the agreement was signed was the collection of data from a form that aimed to characterize the sociodemographic characteristics of the study population (age, marital status, formal education, occupation, family income, and residence/housing situation). In the second stage, we recorded the score obtained from the Audit, aiming to identify the potential risk drinkers, the dynamics of consumption, symptoms of dependence, and the personal and social consequences of drinking in the elderly's life. Since this instrument is simple, its format allowed it to be applied both as an interview or as a self-administered questionnaire. However, despite the preserved cognition, for most of the subjects, the interview format was 
used due to difficulties such as a deficit of vision or due to the interviewee's preference, among others. This scale is composed of 10 questions, and each question has a margin of 0 to 4 , allowing for a final score of 0 to 40 points. The result is given by the following scores: 0 points: nondrinkers; 1 to 7 points: low-risk consumption; from 8 to 15 points: low to moderate; 16 to 19 points: moderate; 20 to 40 points: likely dependency.

According to the standards of Resolution no. 466/2012 by the National Health Council (CNS), who is responsible for standards on research with human beings, the study was performed after approval by the Research Ethics Committee (RET) of Iamspe under the decision no. 1,105,338 and the signing of an ICF by all participants. It should be emphasized that the study did not expose participants to risks of physical, moral, or psychological nature.

For the data analysis, we used the Statistical Package For The Social Sciences (SPSS) version 17.0 and the chi-square test to check the association of the pattern of alcohol consumption in each group. The significance level adopted was $5 \%(p<0.05)$.

\section{RESULTS}

According to the first part of the research, which addressed the socioeconomic aspects of participants, of the 100 elderly respondents, there was a greater number of elderly individuals between the ages of 60 and 79 years (72\%); $43.1 \%$ of elderly people who did not consume alcoholic drinks, and $48.6 \%$ who consumed little of it; $64.3 \%$ of the elderly people over 80 years presented a low-risk consumption. There was a predominance of females, with $77 \%$, of which $54.5 \%$ presented low alcohol consumption. However, a positive correlation was found between male sex and moderate to high alcohol use. Regarding the marital status, $51 \%$ shared their life with a companion, without any

TABLE 1. THE DISTRIBUTION OF THE INTERVIEWEES ACCORDING TO THEIR SOCIODEMOGRAPHIC CHARACTERISTICS AND ALCOHOL CONSUMPTION. SÃO PAULO, 2015.

\begin{tabular}{|c|c|c|c|c|c|c|c|c|}
\hline \multicolumn{9}{|c|}{ Alcohol consumption } \\
\hline & \multicolumn{2}{|c|}{$\begin{array}{c}\text { None } \\
\text { (0 points) }\end{array}$} & \multicolumn{2}{|c|}{$\begin{array}{l}\text { Low } \\
\text { (1 to } 7 \text { points) }\end{array}$} & \multicolumn{2}{|c|}{$\begin{array}{l}\text { Moderate/high } \\
\text { ( } 8 \text { to } 24 \text { points) }\end{array}$} & \multirow[t]{2}{*}{ Total } & \multirow[t]{2}{*}{$\begin{array}{l}\text { p-value } \\
\left(\chi^{2}\right)\end{array}$} \\
\hline & $\mathrm{N}$ & $\%$ & $\mathrm{~N}$ & $\%$ & $\mathrm{~N}$ & $\%$ & & \\
\hline Total & 39 & 39.0 & 53 & 53.0 & 8 & 8.0 & 100 & \\
\hline \multicolumn{9}{|l|}{ Age } \\
\hline 60 to 79 years & 31 & 43.1 & 35 & 48.6 & 6 & 8.3 & 72 & \multirow{2}{*}{0.358} \\
\hline 80 years and older & 8 & 28.6 & 18 & 64.3 & 2 & 7.1 & 28 & \\
\hline \multicolumn{9}{|l|}{ Sex } \\
\hline Women & 32 & 41.6 & 42 & 54.5 & 3 & 3.9 & 77 & \multirow{2}{*}{0.021} \\
\hline Men & 7 & 30.4 & 11 & 47.8 & 5 & 21.7 & 23 & \\
\hline \multicolumn{9}{|l|}{ Marital status } \\
\hline With a spouse & 18 & 35.3 & 26 & 51.0 & 7 & 13.7 & 51 & \multirow{2}{*}{0.095} \\
\hline Without a spouse & 21 & 42.9 & 27 & 55.1 & 1 & 2.0 & 49 & \\
\hline \multicolumn{9}{|l|}{ Formal education } \\
\hline Complete elementary school & 27 & 39.7 & 34 & 50.0 & 7 & 10.3 & 68 & \multirow{2}{*}{0.409} \\
\hline Medium & 12 & 37.5 & 19 & 59.4 & 1 & 3.1 & 32 & \\
\hline \multicolumn{9}{|l|}{ Occupation } \\
\hline $\begin{array}{l}\text { No occupation } \\
\text { (retired/unemployed) }\end{array}$ & 30 & 36.6 & 45 & 54.9 & 7 & 8.5 & 82 & \multirow{2}{*}{0.563} \\
\hline $\begin{array}{l}\text { With occupation } \\
\text { (works / homemaker / other) }\end{array}$ & 9 & 50.0 & 8 & 44.4 & 1 & 5.6 & 18 & \\
\hline \multicolumn{9}{|l|}{ Income (in MS) } \\
\hline With income & 33 & 37.5 & 47 & 53.4 & 8 & 9.1 & 88 & \multirow{3}{*}{0.290} \\
\hline Without income & 2 & 28.6 & 5 & 71.4 & 0 & 0.0 & 7 & \\
\hline Does not know & 4 & 80.0 & 1 & 20.0 & 0 & 0.0 & 5 & \\
\hline \multicolumn{9}{|l|}{ Housing Condition } \\
\hline Rented & 0 & 0.0 & 3 & 75.0 & 1 & 25.0 & 4 & \multirow{3}{*}{0.190} \\
\hline Others & 3 & 23.1 & 8 & 61.5 & 2 & 15.4 & 13 & \\
\hline Owned & 36 & 43.4 & 41 & 49.4 & 6 & 7.2 & 83 & \\
\hline
\end{tabular}


correlation with the use of alcohol. Another important point is the lack of occupation, i.e., idle time as a risk factor (54.9\% of low risk). In the other variables, there was no correlation with alcohol.

After applying the Audit instrument, it was possible to establish a relationship, according to sex, depression, and alcohol consumption. It is possible to note that the presence of women, with $54 \%(\mathrm{~N}=77)$, was higher in relation to men, $21.7 \%(\mathrm{~N}=23)$, although men presented $21.7 \%$ of alcohol consumption of moderate/high risk and 54.5\% of low-risk alcohol consumption. However, the female population, according to the statistics, presented greater significance (0.021) regarding alcohol consumption in relation to the male population, with no association between use exclusively and depression.

In relation to the score from the Audit instrument, we found that $53 \%$ of the participants, without distinction of sex, presented low-risk consumption, so the recommendation was to intervene with guidance and education, as appears in Table 1.

\section{DISCUSSION}

The research sample is significant for females. This finding corroborates the data from a study carried out in Manaus with 317 elderly individuals that aimed to assess the risk of alcohol consumption,

TABLE 2. DISTRIBUTION OF INTERVIEWEES ACCORDING TO SEX, DEPRESSION, AND ALCOHOL CONSUMPTION. SÃO PAULO, 2015.

\begin{tabular}{|c|c|c|c|c|c|c|c|c|}
\hline \multicolumn{9}{|c|}{ Alcohol consumption } \\
\hline & \multicolumn{2}{|c|}{$\begin{array}{c}\text { None } \\
\text { (0 points) }\end{array}$} & \multicolumn{2}{|c|}{$\begin{array}{c}\text { Low } \\
\text { (1 to } 7 \text { points) }\end{array}$} & \multicolumn{2}{|c|}{$\begin{array}{l}\text { Moderate/high } \\
\text { ( } 8 \text { to } 24 \text { points) }\end{array}$} & \multirow[t]{2}{*}{ Total } & \multirow[t]{2}{*}{$\begin{array}{c}\text { p-value } \\
\left(\chi^{2}\right)\end{array}$} \\
\hline & $\mathrm{N}$ & $\%$ & $\mathrm{~N}$ & $\%$ & $\mathrm{~N}$ & $\%$ & & \\
\hline Total & 39 & 39.0 & 53 & 53.0 & 8 & 8.0 & 100 & \\
\hline \multicolumn{9}{|c|}{ Depression } \\
\hline No & 19 & 38.0 & 26 & 52.0 & 5 & 10.0 & 50 & \multirow{2}{*}{0.762} \\
\hline Yes & 20 & 40.0 & 27 & 54.0 & 3 & 6.0 & 50 & \\
\hline \multicolumn{9}{|l|}{ Gender } \\
\hline Women & 32 & 41.6 & 42 & 54.5 & 3 & 3.9 & 77 & \multirow{2}{*}{0.021} \\
\hline Men & 7 & 30.4 & 11 & 47.8 & 5 & 21.7 & 23 & \\
\hline
\end{tabular}

TABLE 1. CORRECTION BETWEEN SCORE X FREQUENCYX RISK LEVELS AND RECOMMENDED INTERVENTION. SÃO PAULO, 2015

\begin{tabular}{|c|c|c|c|c|c|}
\hline \multicolumn{6}{|c|}{$\begin{array}{l}\text { Relationship between score } x \text { frequency, risk levels (classification) } \\
\text { and their respective interventions in the context of the Audit }\end{array}$} \\
\hline Score & $\begin{array}{l}\text { Frequency } \\
\text { (total }=100)\end{array}$ & Classification & Zone & $\begin{array}{l}\text { Suggestion of classification } \\
\text { for the analysis }\end{array}$ & Recommended intervention \\
\hline 0 & 39 & $\begin{array}{c}\text { O points } \\
39 \text { individuals }(390 \%) \\
\text { Nondrinkers }\end{array}$ & 1 & $\begin{array}{c}\text { O points } \\
39 \text { individuals } \\
(390 \%) \\
\text { Nondrinkers }\end{array}$ & Information and education \\
\hline 1 & 29 & \multirow{6}{*}{$\begin{array}{l}1 \text { to } 7 \text { points } \\
53 \text { individuals }(53.0 \%) \\
\text { low-risk consumption }\end{array}$} & \multirow{6}{*}{ I } & \multirow{6}{*}{$\begin{array}{l}1 \text { to } 7 \text { points } \\
53 \text { individuals } \\
\quad(53.0 \%) \\
N \text {-risk consumption }\end{array}$} & \multirow{6}{*}{ Information and education } \\
\hline 2 & 6 & & & & \\
\hline 3 & 11 & & & & \\
\hline 4 & 4 & & & & \\
\hline 6 & 1 & & & & \\
\hline 7 & 2 & & & & \\
\hline 9 & 1 & \multirow{4}{*}{$\begin{array}{c}8 \text { to } 15 \text { points } \\
5 \text { individuals }(5.0 \%) \\
\text { low-moderate }\end{array}$} & \multirow{4}{*}{$\|$} & \multirow{4}{*}{$\begin{array}{c}8 \text { to } 24 \text { points } \\
8 \text { individuals } \\
(8.0 \%) \\
\text { moderate } \\
\text { probable dependency }\end{array}$} & \multirow{4}{*}{$\begin{array}{l}\text { Guidance / intervention / refer- } \\
\text { ral for specialist care }\end{array}$} \\
\hline 11 & 1 & & & & \\
\hline 12 & 1 & & & & \\
\hline 13 & 2 & & & & \\
\hline 16 & 1 & \multirow{2}{*}{$\begin{array}{c}16 \text { to } 19 \text { points } \\
2 \text { individuals }(2.0 \%) \\
\text { moderate }\end{array}$} & \multirow{2}{*}{ III } & & \\
\hline 18 & 1 & & & & \\
\hline 24 & 1 & $\begin{array}{c}20 \text { to } 40 \text { points } \\
1 \text { individual (1.0\%) } \\
\text { probable dependency }\end{array}$ & IV & & \\
\hline
\end{tabular}


given the prevalence of females, with $63.05 \%^{21}$. Still, in similar data, we can see the prevalence of women in health services, which demonstrates a concern in caring for their health, despite social non-acceptance and prejudice ${ }^{22.23}$. On the other hand, elderly women who stay at home, usually widows and alone, socially isolate themselves and make use of alcohol, which also pushes them further away from family members due to fear of judgment ${ }^{24}$. The study also pointed out that the female population has a greater statistical significance (0.021) regarding alcohol consumption in relation to the male population, with no association between use exclusively and depression.

In relation to age and alcohol use, the range of greater representativeness was between 60 and 79 years, ranging in $43.1 \%$ for no consumption and $48.6 \%$ for low consumption. In contrast, males presented $21.7 \%$ of moderate/high risk for alcohol consumption, whereas women presented $3.9 \%$. In a similar study in the region of Braga, Portugal, with 210 elderly, in which $57.6 \%$ were women, although men presented $56.2 \%$, they found a significant association between male sex and risk consumption of alcohol ${ }^{25}$. Age and formal education were not associated with risk consumption. No significant difference was found between alcohol use in patients with and without depression, as well as in the use of alcohol when patients were classified according to the socioeconomic variables (age, marital status, formal education, income, housing conditions).

In relation to the socioeconomic condition, the lack of occupation was a risk factor (54.9\% of low-risk); however, the occupation in another study can be seen as a protector of functional capacity ${ }^{26}$. In addition, idleness causes low self-esteem or greater depressive feeling because it projects a negative self-image. Therefore, work can be considered an important factor in the protection and maintenance of mental health ${ }^{27}$.

In relation to the frequency (Table 1) of the use of alcoholic beverages, according to the criterion of Audit, most elderly people (53\%) present low-risk consumption (1 to 7 points) against 39\% of non-drinkers (0 points), both considered as zone I. In comparison with a study from Manaus that aimed to apply the Audit in an elderly population in 2013, most subjects were also characterized as zone I, with 273 elderly patients $(86.12 \%)$, out of 317 respondents, followed by 34 (10.73\%) in zone II, nine (2.84\%) in zone III, and one
$(0.32 \%)$ in zone IV. The focus of traceability of alcohol use/risk among the elderly may not always take into account only the amount consumed but also its association with medications, clinical conditions, and the very aging process ${ }^{28}$.

\section{CONCLUSION}

With the analysis of the results, it was possible to verify that elderly individuals aged between 60 and 79 years have a greater possibility of exposure to low-risk alcohol consumption. Another important fact is the presence of elderly women in the range of low alcohol consumption, but with no relationship with depression. However, the female presence is expressive in health care services; however, the issue in question is still permeated by prejudices and paradigms and, on the contrary, we found a positive correlation between elderly men and moderate to high use of alcohol, but with little presence in these same spaces of care, which makes us reflect on the importance of public strategies and policies targeted at this population. The lack of occupation, i.e., idle time as a risk factor, also contributes to the use of alcohol. In relation to the Audit, even though it is considered an instrument of traceability in the investigation of alcohol use and can be used in several scenarios, more research is needed to confirm its viability in the elderly population due to the aging process, chronic pathologies, and psychosocial issues, in addition to the paradigms that underlie the act of drinking, making it more difficult to reach an assertive diagnosis. In view of the integral assistance to the individual, as recommended by the Ministry of Health (MOH) by means of the doctrinal principles of the Single Health System(SUS), health professionals should have a holistic approach. Thus, the importance of training professionals is highlighted so they can be prepared to meet this demand, which requires specific care. We expected that the present study could arouse clinical and academic interest that leads to new research, testing new instruments, and aiming for a more efficient and reliable diagnosis so as to establish plans for treatment and care and provide elderly patients an active aging and quality end of life.

\section{Contribution of the authors}

DPB and FCGP, advisors; PCOG, research, and text. 


\section{RESUMO}

OBJETIVO: Identificar o uso, abuso e dependência de álcool em idosos do ambulatório do lamspe, por meio da aplicação do Audit, através da caracterização socioeconômica dos idosos e dos problemas associados pelo consumo e pesar se há relação entre depressão e uso abusivo ou dependência de álcool.

MÉTODOS: Trata-se de um estudo de corte transversal, exploratório e descritivo de abordagem quantitativa. Foram entrevistados cem pacientes idosos para aplicação de um formulário socioeconômico e de avaliação do consumo de álcool, a partir da Audit.

RESULTADOS: Verificou-se correlação entre o consumo de álcool e sexo feminino ( $p=0,021)$. A maioria dos participantes estava na faixa etária entre 60 e 79 anos, era do sexo feminino, tinha companheiro(a), com ensino fundamental completo, renda e casa próprias, era aposentada e desocupada.

CONCLUSÃO: No presente estudo não verificamos correlação entre abuso de álcool e depressão; somente foi encontrada a correlação entre sexo masculino e maior uso abusivo de álcool. No entanto, encontrou-se prevalência significativa de uso moderado a alto de álcool (3,9\% em mulheres e 27,7\% em homens), o que, por si, traz risco para a saúde de idosos.

PALAVRAS-CHAVE: Saúde do idoso. Alcoolismo. Transtornos relacionados ao uso de álcool.

\section{REFERENCES}

1. Organização Mundial da Saúde. Active ageing: a policy framework. Arquivado em 19 de março de 2015, no Wayback Machine. A contribution of the World Health Organization to the Second United Nations World Assembly on Ageing. Madri, abril de 2002. p.4.

2. Papaléo NM. O estudo da velhice: histórico, definição e termos básicos. In: Freitas EV, Py L, Cançado FAX, Doll J, Gorzoni ML, orgs. Tratado de geriatria e gerontologia. $2^{a}$ ed. Rio de Janeiro: Guanabara Koogan; 2006.

3. Instituto Brasileiro de Geografia e Estatística - IBGE. Censo demográfico 2013. [cited 2015 Jun 12]. Available from: www.ibge.gov.br

4. Caetano LM. O idoso e a atividade física. Horizonte - Rev Educ Física e Desperto. 2006;11(124):20-8.

5. Gai |, Gomes L, Nóbrega OT, Rodrigues MP. Fatores associados a quedas em mulheres idosas residentes na com unidade. Rev Assoc Med Bras. 2010;56(3):327-32.

6. Muniz EA, Aguiar MFS, Brito MCC, Freitas CASL, Moreira ACA, Araújo CRC. Desempenho das atividades básicas da vida diária de idosos em Atenção Domiciliar na Estratégia Saúde da Família. Rev Kairós Gerontol. 2016;19(2):133-46.

7. Feitosa ANC, Ferreira LA, Oliveira AM, Feitosa IKC. O uso de substâncias psicoativas em idosos. Id on Line Rev Psicol. 2016;10(30 supl 2):245-51.

8. Figlie NB, Bordin S, Laranjeira R. Aconselhamento em dependência química. $2^{a}$ ed. São Paulo: Roca; 2010.

9. Aguiar AS, Catelli R, Toledo L, Ubaldo L, Silva CI, Fonseca VAS. Estudo da atitude diante do paciente alcoolista e do conhecimento sobre alcoolismo em função do padrão de beber de estudantes de Medicina. Rev Bras Educ Med. 2018;42(3):49-56.

10. Kalinowski A, Humphreys K. Governmental standard drink definitions and low-risk alcohol consumption guidelines in 37 countries. Addiction. 2016;111(7):1293-8

11. Phillips $P$, Katz $A$. Substance misuse in older adults: an emerging policy priority. NT Research. 2001;6(6):898-905.

12. Levin SM, Kruger L. Substance abuse among older adults: a guide for social service providers. Rockville: U.S. Department of Health and Human Services, Substance Abuse and Mental Health Services Administration. Center for Substance Abuse Treatment; 2000

13. Pillon SC, Cardoso L, Pereira GAM, Mello E. Perfil dos idosos atendidos em um centro de atenção psicossocial: álcool e outras drogas. Esc Anna Nery. 2010;14(4):742-8.

14. Santos AS, Viana DA, Souza MC, Meneguci J, Silveira RE, Silvano CM, et al. Atividade física, álcool e tabaco entre idosos. REFACS. 2014;2(1):6-13.
15. Bommersbach T], Lapid MI, Rummans TA, Morse RM. Geriatric alcohol use disorder: a review for primary care physicians. Mayo Clin Proc. 2015;90(5):659-66.

16. World Health Organization. International Statistical Classification of Diseases and Related Health Problems 10th Revision - ICD10. Version: 2010. Geneva: World Health Organization; 2010.

17. Cantão L, Fonseca LLK, Silva TIM, Oliveira M, Oliveira VC, Machado RM Perfil sociodemográfico e clínico de idosos com depressão e o uso de substâncias psicoativas. Rev Rene. 2015;16(3):355-62.

18. Ministério da Saúde. Datasus. Estatísticas vitais. Mortalidade geral. Transtornos mentais e comportamentais. Episódios depressivos e transtornos depressivos recorrentes. [Internet] 2012 [cited 2014 Set 08]. Available from: http:// tabnet.datasus.gov.br

19. Babor TF, Higgings-Biddle IC, Sauders |B, Monteiro MG. AUDIT: teste para identificação de problemas relacionados ao uso de álcool: roteiro para uso em atenção primária. Ribeirão Preto: Programa de Ações Integradas para Prevenção e Atenção ao Uso de Álcool e Drogas na Comunidade; 2003.

20. Gil AC. Como elaborar projetos de pesquisa. 4ª ed. São Paulo: Atlas, 2007.

21. Costa ACS. Adaptação dos pontos de corte do AUDIT entre idosos da ESF em Manaus, AM. 2014. [cited 2019 Sept 6]. Available from: http://riu.ufam. edu.br/handle/prefix/4002

22. Galato D, Silva ES, Tiburcio LS. Estudo de utilização de medicamentos em idosos residentes em uma cidade do sul de Santa Catarina (Brasil): um olhar sobre a polimedicação. Ciênc Saúde Coletiva. 2010;15(6):2899-905.

23. Pereira IC, Barreto SM, Passos VMA. O perfil de saúde cardiovascular dos idosos brasileiros precisa melhorar: estudo de base populacional. Arq Bras Cardiol. 2008;91(1):1-10

24. Barbosa MB, Pereira CV, Cruz DT, Leite ICG. Prevalência e fatores associados ao consumo de álcool e de tabaco em idosos não institucionalizados. Rev Bras Geriatr Gerontol. 2018;21(2):123-33.

25. Martins A, Parente |, Araújo |, Menezes M|. Prevalência do consumo de risco de álcool no idoso: estudo numa unidade dos cuidados primários da região de Braga. Rev Port Med Geral Fam. 2018;32(4):270-4.

26. Freitas RS, Fernandes MH, Coqueiro RS, Reis Júnior WM, Rocha SV, Brito TA. Capacidade funcional e fatores associados em idosos: estudo populacional. Acta Paul Enferm. 2012;25(6):933-9.

27. Beck LM, David HMSL. Drug abuse and workplace: possibilities to nurse actuation. Esc Anna Nery Rev Enferm. 2007;11(4):706-11.

28. Fink A, Tsai MC, Hays R D, Moore AA, Morton SC, Spritzer K, et al. Comparing the alcohol-related problems survey (ARPS) to traditional alcohol screening measures in elderly outpatients. Arch Gerontol Geriatr. 2001:34(1):55-78 